\title{
Ornamental plants and the production of nature(s) in the Spanish real estate boom and bust: the case of Alicante
}

\author{
María Hernandez ${ }^{\mathrm{a}}$, Alfredo Morales ${ }^{\mathrm{a}}$ and David Sauri ${ }^{\mathrm{b} *}$ \\ ${ }^{a}$ Universdad de Alicante, Alicante, Spain; ${ }^{b}$ Departament de Geografia, Universitat Autònoma de \\ Barcelona, 08193 Bellaterra, Spain
}

(Received 22 March 2013; accepted 6 September 2013)

\begin{abstract}
The Spanish real estate boom and bust of the 2000s caused immense economic, social, and environmental changes across the country. Massive urbanization, however, does not necessarily entail the end of nature and natural processes, instead marking a radical transformation of environments and societies. Through a political ecology approach, we analyze how ornamental species have become a fundamental part of new natures induced by urbanization in the Spanish province of Alicante. We connect the economic and ecological characteristics of ornamental plants like the palm tree to urbanization and real estate trends in Alicante. Our evidence indicates that, in Alicante, economic recession and environmental crises (manifested in the pests affecting palm trees) have mutually reinforced one other, creating a new geography of ecological desolation in many areas.
\end{abstract}

Keywords: ornamental plants; political ecology; urbanization; real estate; crisis; Spain

\section{Introduction}

In January 2013, one of the main Spanish producers of ornamental plants, based in Sagunto (a northern suburb of the city of Valencia), decided to uproot and destroy more than 3,000 palm trees of the species Phoenix canariensis. According to the company, this action was prompted by the impossibility of financing costly treatments for trees affected by the Red Weevil (Rhynchoforus ferrugineus), a beetle currently infesting many palm orchards in Mediterranean Spain (Europa Press, 2013). In the background of this decision loomed the economic crisis that followed the collapse of the Spanish real estate bubble in 2008. In this paper we elucidate a connection between the Spanish financial and housing crisis and the production and demand for ornamental plants in residential and public areas. We argue that a new, post-crisis nature has emerged; this new nature is characterized by both market and ecological characteristics of ornamental plants and by decisions made by individuals and municipalities as they adapt to the financial downturn.

For the purposes of this paper, ornamental plants are defined as being cultivated or commercialized for a decorative purpose, usually associated with gardening or landscaping. Ornamental plants are one of a myriad of residential commodities associated with urbanization and especially with suburban living. In Mediterranean Spain, they are present in the gardens of sprawling urban communities and also in the public infrastructure created to facilitate private transportation to new suburban spaces, such as

*Corresponding author. Email: David.sauri@uab.cat 
roundabouts, avenues, squares, and plazas. In rapidly urbanizing Mediterranean Spain, these plants have partially replaced agricultural crops and native vegetation. In sum, ornamental plants, especially emblematic species like the palm tree, have come to exemplify the new landscapes or the new natures associated with contemporary urbanization along the Mediterranean coast (European Environmental Agency, 2006; Munoz, 2003).

In this paper we examine the role of ornamental plants in the creation of new "natures" after the massive urbanization process and subsequent real estate bubble in the Alicante province of the Spanish Comunidad Valenciana [Valencia Autonomous Community] (see Figure 1). We take a political ecology approach and also frame this production of nature as induced by urbanization (Smith, 1984). We contend that the strict separation of nature and society, which is commonly associated with analyses of urbanization, does not adequately explain the post-crisis economy and ecology of Alicante. We argue that while urbanization may disrupt existing natures and social relations, it is simultaneously an active agent in the creation of new natures and societies, which are geographically and historically specific (Heynen, 2006; Peet, Robbins, \& Watts, 2010; Robbins, 2004). In this sense, ornamental plants and their particular ecological relations form part of a produced nature that is characteristic of urban sprawl and its proliferation of human and nonhuman artifacts and relations-houses, gardens, swimming pools, highways, shopping malls, roundabouts, and the like. We investigate ornamental plants not only as objects of agricultural production but also as commodities that are deeply embedded in the urbanization process.

An examination of ornamental plants, specifically the palm tree, also offers a clear example of how the current crisis in Spain can be defined as a socioecological crisis. That

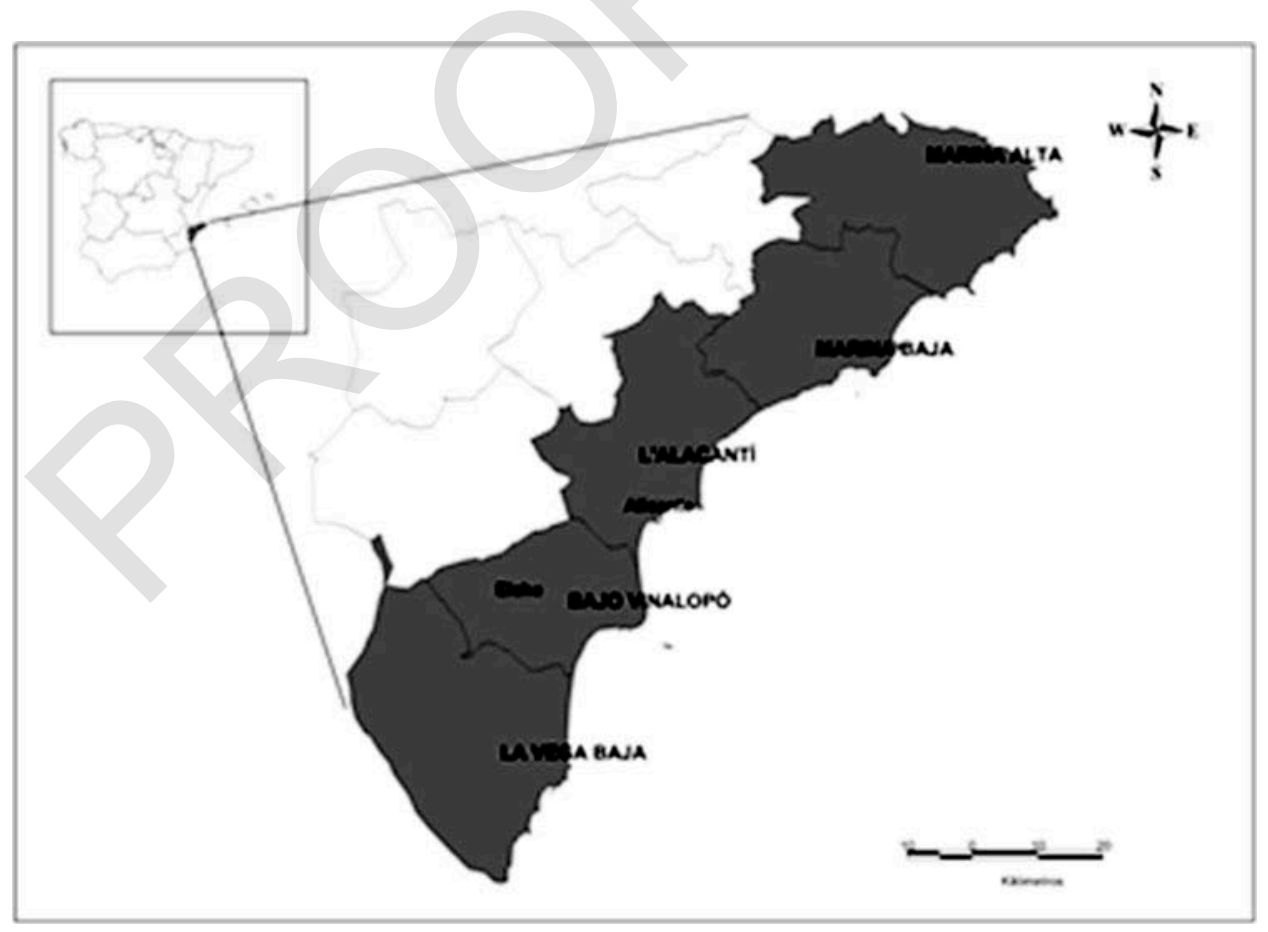

Figure 1. The province of Alicante (Comunidad Valenciana, Spain). 
is, the consequences of Spain's real estate crash are borne by both the human and nonhuman worlds. We argue that the financial impossibility of addressing a plague that is destroying palm trees, one of the symbols of the new suburban spaces in Alicante, is a manifestation of this crisis-induced socioecological malaise. While ornamental plants are active agents in the creation of new suburban natures in Alicante, they are also subject to the same process of demise and collapse currently affecting many suburban enclaves in our study area.

The paper is organized as follows. First, we review the political ecology literature on the relationship between urbanization and nature. Second, we discuss the characteristics and recent evolution of ornamental plants in Spain and Alicante. In the third section, we focus on recent urban growth and the main reasons behind what has been called the "urbanization tsunami" of the 2000s (Gaja, 2008). Fourth, we explore the dynamics of ornamental plants and their production, and particularly the ascent and demise of the palm tree, which we link to the contemporaneous ascent and collapse of the real estate market. To conclude, we consider, more broadly, the connections between urbanization and attendant socioecological change in Alicante.

\section{The political ecology of ornamental plants and gardens}

The cultivation of plants for aesthetic or landscaping purposes is ubiquitous in the history of human relations with the nonhuman world (Turner, 2010). Under advanced capitalism, certain plants, trees, and their cultivation in gardens are interwoven with the urbanization process, particularly through low density urbanization or urban sprawl. The dominant model of this form of urbanization is the Anglo-European single house (or condominium), which often includes a garden and, in certain climates, a swimming pool (Askew \& McGuirk, 2004; Leichenko \& Solecki, 2005). In this sense, gardens are examples of new natures emerging through urbanization, taking the form of assemblages of species and ecological relationships (Domene \& Saurí, 2007). These new assemblages can radically restructure nature-society relations, for example through the introduction of species characteristic of certain climates in areas with different climatic conditions (Parés, March, \& Saurí, 2013). One of the best examples of these natures is the lawn, which has become a fundamental constituent of American suburban landscapes in social, spatial, and environmental terms (Blaine, Clayton, Robbins, \& Grewal, 2012; Robbins, 2007).

Broadly, from a political ecological perspective, urbanization implies the transformation of nature and of natural processes. This does not mean (as is often assumed) that cities are the antithesis of nature. Rather, urban areas are socioecological constructions that are different than, say, those of agricultural areas, but equally subject to both natural and social processes (Harvey, 1996; Swyngedouw, 2004). New assemblages of urban/ suburban socionatures thus create dynamic but path-dependent tradeoffs between the priorities of urban climate change adaptation strategies, continued growth, water consumption, and the aesthetics of residential landscapes in arid and semiarid environments (Gobert et al., 2012).

We argue here that ornamental plants and trees are fundamental components of the new natures emerging during rapid urbanization in Alicante in the first years of the twenty-first century. Our approach focuses on the agents and processes, both 'natural' and social, that have governed the ascendancy and subsequent decline of ornamental plant production and cultivation. Although the natural and cultural dimensions of gardens, both public and private, have been well-researched (see Bhatti \& Church, 2004), fewer 
researchers have addressed the relevance of ornamental plants within the agricultural sector or the relation between ornamental plant production and the urbanization process. In this sense, our purpose is to link specific historical trajectories of urbanization, such as those occurring in Alicante, with the constitution of new natures in which ornamental plants play a primary role.

\section{The business of ornamental plants in Spain and Alicante}

Ornamental plants and flowers have received little attention in rural and agricultural analyses of Spain for two main reasons. The first is their limited presence in terms of cultivated land. In 2010, ornamentals only occupied some 6,000 hectares of agricultural land, or less than $0.01 \%$ of the Spanish total (Ministerio de Agricultura, Alimentación y Medio Ambiente, 2012). Second, ornamentals are almost invisible in traditional agricultural landscapes since most of the species are grown in greenhouses. The use of greenhouses means that ornamental species are not easily visible as agricultural production outputs, with the exception of certain trees. Furthermore, in Spain, the fragmentation of land devoted to ornamentals adds to this lack of visibility. ${ }^{1}$

Despite its relative invisibility, the sector of ornamental trees, plants and flowers is likely the most productive sector in Spanish agriculture. In terms of jobs, ornamental species employ between five and six UTAs (working-units per year) per hectare whereas, for instance, cereals employ 0.08 UTAs per hectare, and citrus fruits employ 0.4 UTAs per hectare (Hernández Hernández \& Morales Gil, 2009; Morales Gil, 1997). In the Valencia region, the 1,600 hectares devoted to ornamental species created some 8,850 full time jobs in 2011, which dwarfs (proportionally) the 10,350 jobs created in Spain's 70,000 hectares of vineyards. Moreover, between $70 \%$ and $80 \%$ of the jobs associated with ornamentals are permanent jobs, again in contrast with cereals or citrus fruits, where temporary labor is more common. Additionally, farms devoted to ornamental plants and flowers have shown a remarkable capacity to absorb workers laid off by the manufacturing and service sectors in the wake of the economic crisis.

In economic terms, returns from ornamentals rank among the highest in Spanish agriculture. The value of the production of vegetable orchards, ornamental plants, and flowers in 2001 approached $€ 6.7$ billion, or $27.5 \%$ of the total value of the Spanish agricultural output (in comparison, wine represented a mere 3.9\%) (de Agricultura \& Ambiente, 2012). The bulk of such value lies in the vegetable orchards under plastic, ${ }^{2}$ but from a productivity standpoint, ornamentals appear at the top of productivity for Spanish agriculture. Likewise, ornamentals have usually been net contributors to the Spanish AQ2 balance of payments during the last decade (Figure 2).

Within the ornamental sector, however, it is important to differentiate between those ornamentals (most notably flowers and small plants) grown in greenhouses and requiring important inputs in the form of water and fertilizers and ornamentals grown in open-air nurseries that, in the cases of palm and olive trees, thrive in the traditional Mediterranean and semiarid landscapes and are less resource-demanding than the other groups. A crucial difference is in the water requirements. Flowers usually need up to 10,000 cubic meters per hectare per year while palms, olive trees, and shrubs need only between 2,000 and 3,000 cubic meters per hectare per year. However, the productivity of water for flowers, compared with other agricultural produce, is very high: the productivity of water for flowers can be up to $€ 3$ per cubic meter in greenhouse species compared to $€ 0.55$ per cubic meter for citrus orchards or $€ 0.18$ per cubic meter in the case of cereals (Melgarejo, Martínez, \& Martínez, 2004). 


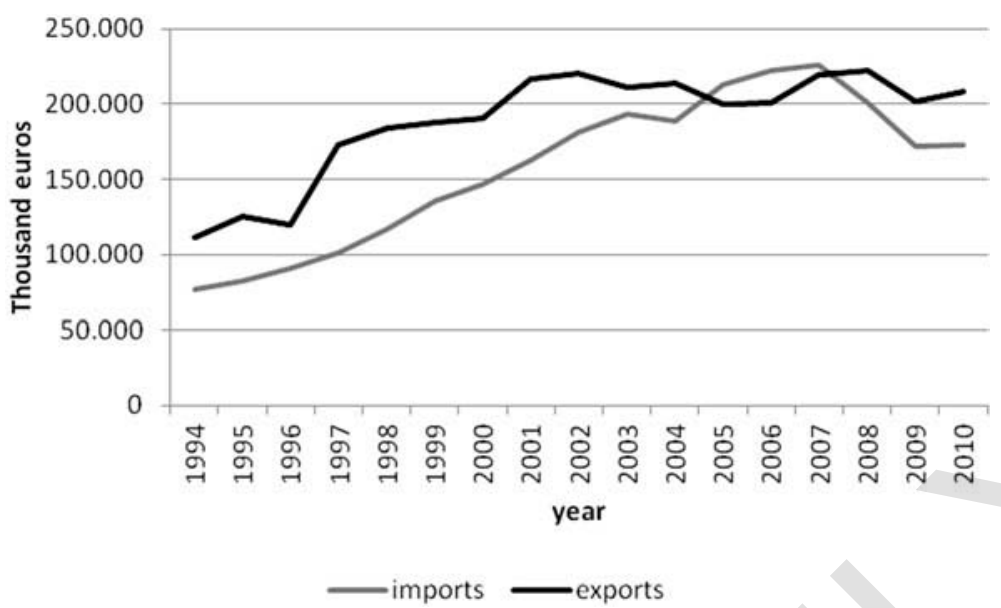

Figure 2. Value of Spanish imports and exports of ornamental plants and flowers (in thousand $€$ ). Source: Adapted from the Instituto Español de Comercio Exterior, 2012.

Examining the evolution of agricultural land dedicated to flowers and ornamental plants during the past decade offers some insights regarding a possible relationship with the urbanization process. Between 1997 and 2010, agricultural land dedicated to flowers and ornamental plants and trees in Spain rose from around 2,000 hectares to 5,100 hectares. More significantly, while in 1997 land devoted to ornamental plants and trees represented $43 \%$ of the total category of "ornamental plants and flowers," by 2011 , it had jumped to $75 \%$ of the total (de Agricultura \& Ambiente, 2012). To a large extent, the overall increase in land area observed in the past 15 years is due to a growth of outdoor nurseries for ornamental species, especially palm trees. In regional terms, the largest growth was concentrated in Catalonia, especially around Barcelona, but the Valencia region came in a close second, with more than 1,500 hectares (see Figure 3). As we explain below, the years of expansion in ornamentals show a remarkable coincidence with the years of fast urbanization in coastal Mediterranean Spain.

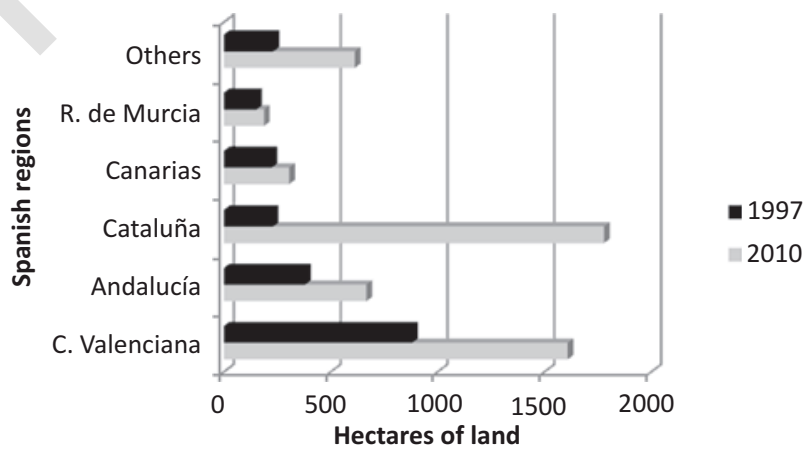

Figure 3. Area cultivated with ornamental species (in hectares). Spanish regions. 1997 and 2010. Source: Adapted from Ministerio de Agricultura, Alimentación y Medio Ambiente (2012). 


\section{The real estate bubble and the socioenvironmental change in Mediterranean} Spain

The magnitude of urban growth in Spain between 1990 and 2008 was striking in duration and intensity, to the extent that it has been referred to as a "tsunami" (Gaja, 2008). But an abrupt decline began in 2008, resulting in bankruptcies, evictions, mass political corruption at all scales, and a radical transformation of national, regional, and local societies and environments, especially along the Mediterranean coast. The rapid growth and collapse of urbanization is not a uniquely Spanish phenomenon; real estate bubbles in the developed world (Japan, the United States or Ireland, to mention just a few cases) often trigger more profound periods of economic recession. Nevertheless, Spain represents an extreme case of urban development followed by urban collapse (Gonzaléz, 2010; Naredo Antrazyt \& Montiel Márquez, 2011).

After the opening up of land-use laws in 1998, and during the subsequent period of abundant money at low interest rates, the Spanish building frenzy resulted in construction of more housing units (apartments, condominiums, and single houses) than in France, Germany, and the United Kingdom combined (Burriel de Orueta, 2008). Between 1997 and 2007, the number of housing units grew from 19.6 million to 24.2 million. ${ }^{3}$ In terms of land occupation, urban uses (including infrastructure) expanded from some 670,000 hectares in 1987 to more than one million hectares in 2006 (Observatorio de la Sostenibilidad en España, 2011). That much of the expansion was based on speculative investment is evidenced by the differences between the population growth and the increase of housing units. Thus, while population in Spain grew $0.93 \%$ annually between 1991 and 2010, the housing stock grew at a rate of 3.4\% annually during the same period. Alongside housing bought as an investment, another major part of demand was European retirees. In this respect, between 2001 and 2011, Valencia grew by approximately one million people, of which approximately 800,000 were foreigners. A total of 500,000 of these were Europeans from other parts of the continent.

Forty-eight percent of the Spanish housing stock built between 2000 and 2011 was constructed in the Mediterranean provinces, and Valencia was the third largest community in the number of housing units built between 1997 and 2008. The province of Alicante occupied the third position in the ranking of Spanish provinces according to the number of housing units built between 2001 and 2008 (345,410), and it ranked fifth in population (after Madrid, Barcelona, Valencia, and Seville). In part these figures reflect changes in tourist accommodations, with the proportion of hotels decreasing in favor of an increased preference for renting apartments, condominiums, and villas (see Table 1). In Alicante about $35 \%$ of the new housing units built between 2000 and 2006 were single houses and condominiums. Although this figure had declined to $25 \%$ of the total in 2006 , it illustrates the ascendancy of low density urban growth in Alicante (Hernandez \& Hernandez, 2013).

Urban expansion, particularly in low density form, had an important impact on local finances. Although figures may vary depending on the size of the municipality, local finances expanded enormously in the first half of the 2000s. Doubling or tripling of municipal budgets was not uncommon in Alicante. The municipality of San Fulgencio, for instance (4,000 people in 2001; more than 12,000 in 2009) went from a municipal budget of $€ 4.4$ million in 2001 to almost $€ 15$ million in 2003. Taxes drawn from these new urban developments largely explain this increase in revenue. Another factor in urban expansion was the purchase of housing stock by European immigrants, usually retirees from the Central and Northern parts of the continent. The Spanish market provided affordable housing and credit conditions while allowing retirees to benefit from free or inexpensive 
Table 1. Number of housing units and built area (2000-2011) in Spanish Mediterranean Provinces.

\begin{tabular}{lrrrcr}
\hline & $\begin{array}{c}\text { Housing } \\
\text { units }\end{array}$ & $\begin{array}{c}\text { Built } \\
\text { area }\left(\mathrm{m}^{2}\right)\end{array}$ & \multicolumn{1}{c}{$\begin{array}{c}\text { Population } \\
2011\end{array}$} & $\begin{array}{c}\text { Housing units/Spanish } \\
\text { total }(\%)\end{array}$ & $\begin{array}{c}\text { Population/Spanish } \\
\text { total }(\%)\end{array}$ \\
\hline Spain & $5,668,047$ & $931,758,647$ & $47,212,990$ & - & - \\
Alicante & 345,410 & $50,995,114$ & $1,940,956$ & 6.09 & 4.11 \\
Almería & 154,513 & $22,047,778$ & 702,997 & 2.73 & 1.49 \\
Baleares & 118,069 & $20,493,084$ & $1,118,654$ & 2.08 & 2.37 \\
Barcelona & 405,086 & $67,519,498$ & $5,549,224$ & 7.15 & 11.75 \\
Castellón & 171,849 & $25,837,479$ & 604,358 & 3.03 & 1.28 \\
Girona & 132,727 & $15,702,272$ & 760,722 & 2.34 & 1.61 \\
Granada & 137,325 & $23,215,599$ & 920,151 & 2.42 & 1.95 \\
Málaga & 290,717 & $47,427,613$ & $1,639,127$ & 5.13 & 3.47 \\
Murcia & 292,708 & $48,724,343$ & $1,472,837$ & 5.16 & 3.12 \\
Tarragona & 164,235 & $24,990,555$ & 813,287 & 2.90 & 1.72 \\
Valencia & 274,623 & $48,363,254$ & $2,578,197$ & 4.85 & 5.46 \\
Total & $2,487,262$ & $395,316,589$ & $18,100,510$ & 48.33 & 38.33 \\
\hline
\end{tabular}

Source: Adapted from Ministerio de Fomento and Instituto Nacional de Estadística.

health care and social services (Huete Nieves \& Mantecón Terán, 2011). Many retirees with more moderate incomes were settled in the less expensive southern parts of the province. So as to pay less for garden maintenance, these people tended to adapt their Ad4 gardens to species that demanded relatively little water (Figure 4). ${ }^{4}$

If the Spanish real estate boom has no match in Europe, the sharp decline in housing development since 2007 is equally unknown in the continent. The almost 667,000 new housing construction started in 2007 decreased to less than $10 \%$ of this number in 2010 (see Figure 5) leaving behind heavily indebted public institutions, most notably regional governments and local councils. The consequences of the real estate collapse can be readily observed in the landscape in the form of "skeletons of concrete" ready to be taken back by local natures and dotting many areas of the Mediterranean coast and of Alicante (see Figure 5).

Since 2008, local budgets have suffered a significant decline. ${ }^{5}$ On average, the 2009-2011 budgets of large Spanish municipalities had been reduced between $40 \%$ and $70 \%$ in comparison with the average budgets of 2003-2005 (Ministerio de Hacienda y Administraciones Públicas, 2012). For example, revenue for San Fulgencio fell from $€ 15$ million in 2003 to $€ 8.8$

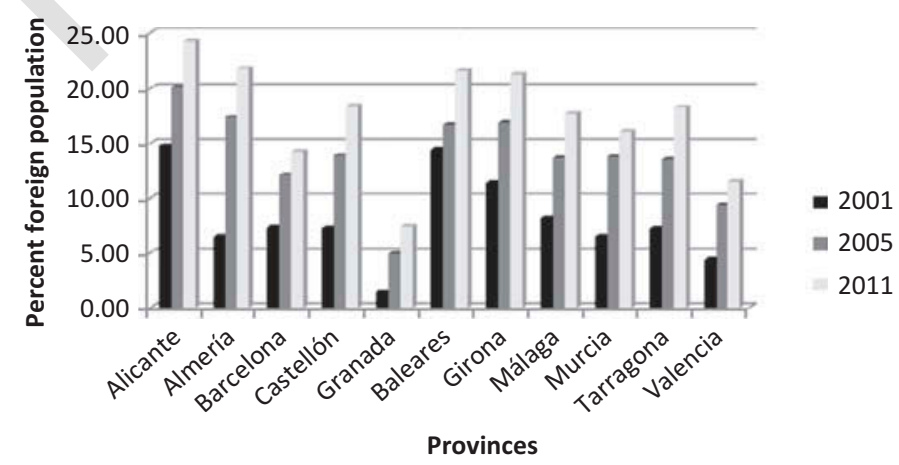

Figure 4. Foreign population in the Spanish Mediterranean coast (percentage over total population) in 2001, 2005, and 2011.

Source. Adapted from Instituto Nacional de Estadística. 


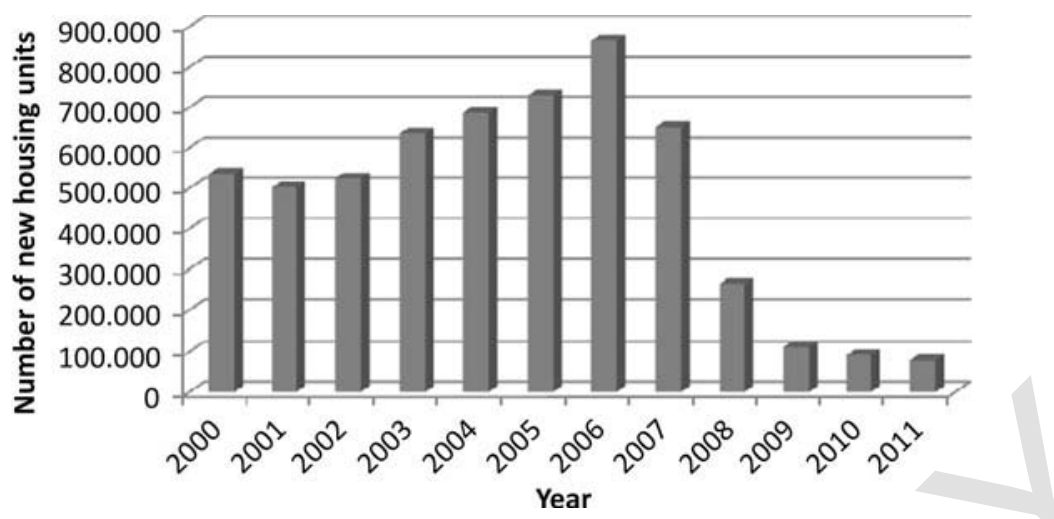

Figure 5. Number of new housing units for residential purposes. Spain (2000-2011). Source: Adapted from Ministerio de Fomento.

million in 2012. An important proportion of this decline occurred in the category of "Indirect Taxes," which is linked to real estate activity. In San Fulgencio, revenue in this category 235 decreased from $€ 1.6$ million in 2005 to $€ 370,000$ in 2012.

Increasing debt payments and declining revenues had devastating repercussions in public gardens and public landscaping. However, in many cases these effects have been attenuated because contractors have continued to fulfill their duties even under situations of payment defaults (or important reimbursement delays) by local councils. At any rate, 240 the collapse in the real estate market in Alicante has left many developments with unfinished or no landscaping (see Figure 6).

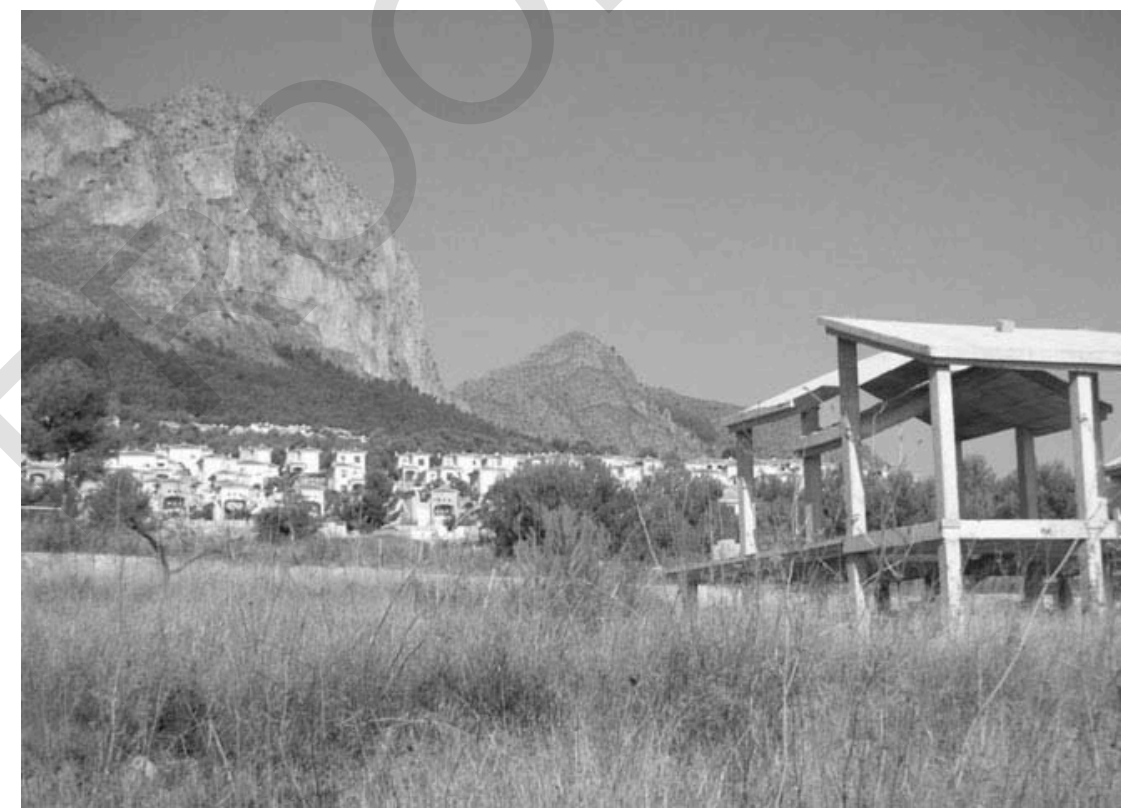

Figure 6. "Skeletons of concrete". Unfinished housing in Polop de la Marina (Alicante). Source: Photo by authors. 


\section{Ornamental plants in Alicante: from boom to bust}

The production and consumption of ornamental plants in Alicante offers interesting contrasts between the north and the south of the province, regarding both ecology and the particular history of urbanization in each region. These differences tend to reflect distinct histories of the urbanization process in both areas. In general terms, while production of ornamentals is essentially concentrated in the south, demand and consumption, measured through the number of garden centers and landscaping firms and their sales, are for the most part located in the north. In the north, residential development has mostly taken the form of single, detached houses with a significant presence of private gardens, swimming pools, and generally wealthier households. In the south, residential developments have, more recently, taken the form of more modest condominiums with shared gardens and swimming pools, and apartment blocks with common facilities. Hence, garden areas in the south tend to be smaller than in the north.

In the south, demand for ornamentals comes increasingly from the retired immigrants of Central and Northern Europe who have purchased homes inland and away from the coastal zone; these areas are heavily developed with high rise apartment blocks. Garden centers are not as common as in the north and clients increasingly purchase ornamental plants directly from producers, most notable those specializing in plants and small shrubs. Regarding the distribution of types and genera, species not adapted to local climatic conditions are generally ignored because of high water prices and complicated maintenance. Therefore, ornamentals with low water requirements dominate the markets. Besides palms, the most popular ornamental tree is the olive tree.

Olive trees in this area present an interesting change in the relationship between humans and certain species. Olive trees were fundamental constituents of the so-called Mediterranean crop trilogy, which also includes wheat and vineyards. In Alicante (almost at their precipitation limits), olive trees were cultivated in terraces built on ephemeral water courses so they could access shallow water tables. Until the 1990s, their use as ornamentals in Alicante was rare. The olive tree's introduction, a decade after the trees became popular in Italian landscaping design, coincided with the years of Spain's construction boom. But the most distinctive ornamentals in the new suburban spaces of Alicante are palm species, the dwarf palm (Chamareops humilis), and the Phoenix canariensis, Washingoniana robusta, and Trachycarpus fortunei. Palm trees and, in particular, these three species, are well-suited to rapidly urbanizing spaces. They grow quickly and are aesthetically pleasant. Furthermore, they are also inexpensive, require little maintenance, and do not need large quantities of water.

Trends in cultivated areas and in the production of ornamental plants in Alicante have roughly followed national trends, with elevated intensity due to the magnitude of the urbanization process in this province. Given the association between urbanization and ornamental plant cultivation, the real estate crisis reconfigured the production of ornamentals in Alicante in several ways. As far as plants and trees are concerned, the collapse of residential construction and the drastic decline in local budgets have produced substantial reductions in demand. Regarding flowers, the market expansion of Colombia and Southeast Asia species at competitive prices have affected demand for domestic production: local flowers such as roses and carnations are increasingly unable to compete with tropical producers. Figure 7 illustrates changes in Alicante's production of ornamental species.

Natural conditions, particularly the length of the growing season, determine producers' ability to adapt to changes in the real estate market and trends in the urbanization 


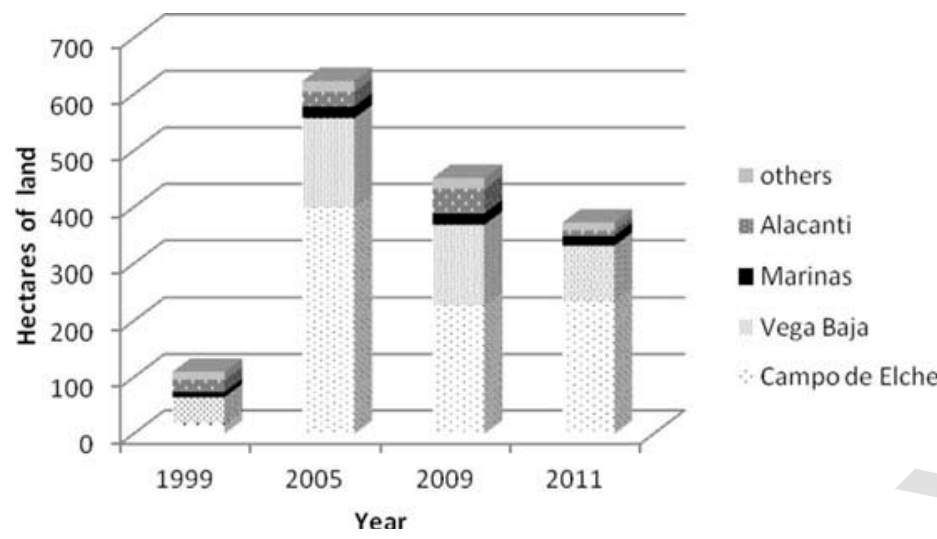

Figure 7. Area cultivated with ornamental species for Alicante counties (1999-2011).

Source: Adapted from Conselleria de Agricultura (Generalitat Valenciana) (2008).

process. Seasonal (one-year cycle) plants and shrubs offer almost instantaneous adaptability, while the longer growing cycles of large shrubs and trees (up to eight years for certain species) complicate adaptation to changing conditions in the real estate market. Hence, farms specializing in larger plants and trees have suffered particularly hard from the real estate crisis. Palms and olive trees have experienced the heaviest impacts. During the years of the real estate boom, a 1000-year-old olive tree could sell for $€ 6,000$, though palm trees were much cheaper. Depending on the height and trunk size, prices per palm tree were as high as $€ 320$ for the Washintoniana robusta species. The collapse in the market since 2009 has reduced these prices considerably (Confederación Española de Agricultores y Ganaderos, 2010; Federación de Cooperativas Agrarias de Murcia, 2013). Competition from Italy has also taken a heavy toll on local producers.

Although percentages vary slightly by year, in general, garden centers supply $45 \%$ of the total demand for ornamentals, followed by large retailers $(31 \%)$, small retailers and the public in general (14\%), and public institutions (9\%). Again, however, percentages vary according to specific purchasers. Smaller ornamentals are mostly purchased by individuals. The number and dispersion of garden centers and small farms facilitates purchases by clients living in nearby cities. For large shrubs and trees, most of the demand comes from large retailers and public institutions. The proportion of these species sold to the general public (although growing) is less than 5\% of the total sales. Local and provincial councils purchase palm trees (Chamaerops humilis, Washingtonia robusta, Phoenix canariensis, Phoenix dactylifera, and chamaerops excelsa) and olive trees for the landscaping of public space in newly urbanizing areas. During the years of the real estate boom, the owners of new houses and condominiums also purchased these and other species for shared outdoor areas.

Figure 8 shows the sales of ornamentals by group in 2007, a booming year for commercial production of ornamental plants. Flowerbeds dominate sales but the second largest group is palms (more than 600,000 units). Aromatic plants, shrubs, and trees (most of them olive trees) are also quite popular, while the rest of the categories lag far behind. Finally, lawns are relatively rare in the area mostly because of very high maintenance costs, especially in the more arid southern part of the province. However, in some public landscaping such as road and street rotaries it is not uncommon to find small lawns on 


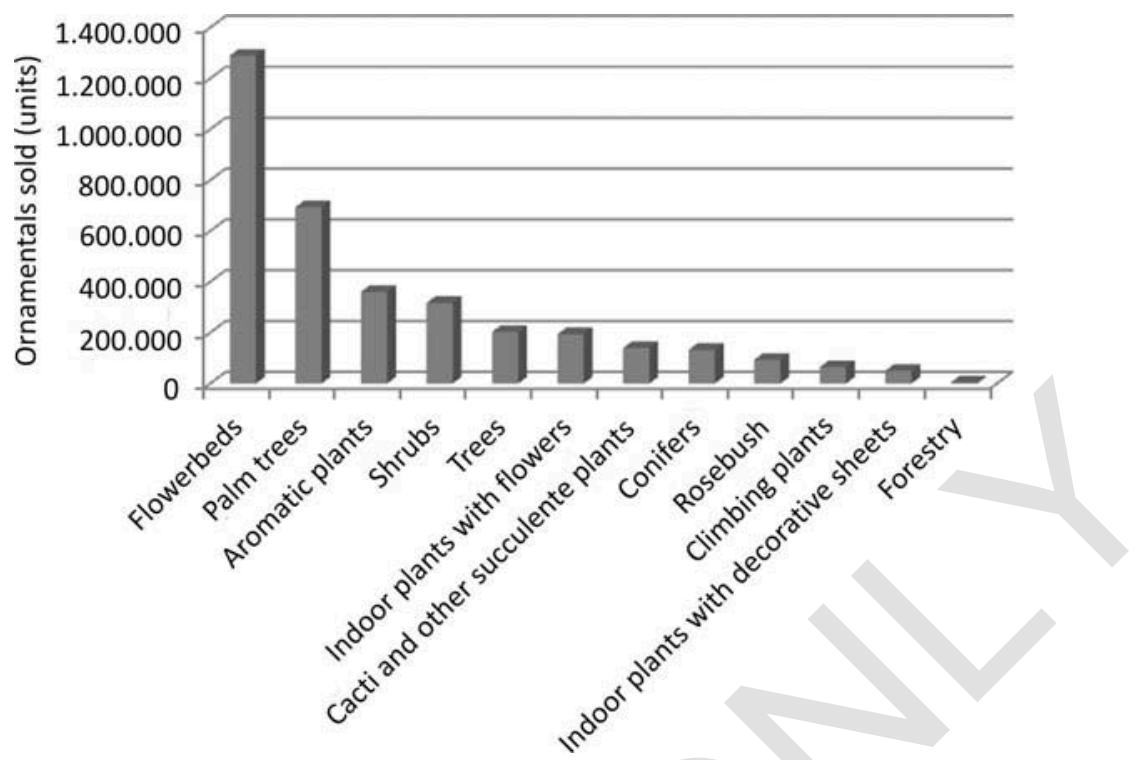

Figure 8. Sales of ornamental species by groups (units), 2007.

Source: Adapted from Conselleria de Agricultura (Generalitat Valenciana) (2008).

which plants, shrubs, and trees are also planted. In this case, lawns are irrigated with water free of charge for the municipalities and serve to satisfy certain preferences for green vegetation by people living in mostly brownish landscapes.

Since 2007-2008, however, ornamental production and purchase in Alicante have experienced a period of decline. First, the collapse in the housing market substantially decreased sales to private citizens; the finances of local municipalities were reduced to an extent that plants in public spaces were no longer funded. This decreased the amount of land devoted to cultivation and reduced expenditure on maintenance and other items. ${ }^{6}$ Second, the collapse in the price of palm trees that ensued many farms to abandon these species and focus on other ornamental plants and on flowers. Finally, a third factor concerns the devastating effects of the Red Weevil, a beetle of the curculionidae family, first discovered in 2004, which perforates the trunk of a palm tree in order to feed from the sap. This invasive species arrived in Alicante via Southeast Asia through infected palm trees from Egypt and other Northern African countries. The biological cycle of the insect, after the female lays some 300-500 eggs in the leaves, takes place entirely in the palm tree. Larvae enter the trunk through existing cracks and begin to excavate tunnels that can be more than a meter in length. In one year, the Red Weevil is able to complete three biological cycles; it remains in one tree until the tree has been completely destroyed. Treatment of palm trees is complicated by difficulties in identifying an infestation before tree death occurs.

Strict legislation against the Red Weevil and the complicated and expensive treatments have increased costs, reduced profitability margins, and therefore caused losses for producers. Treatment includes the application of an expensive pesticide, pruning, and also controlled burning of waste. The pesticide's success rate is uncertain. Pruning may be often counterproductive since it facilitates the penetration of the bug while waste must be disposed in such a way that larvae cannot travel to other trees. For these reasons, the most 
common action is the elimination of affected trees and those suspected of hosting the insect. Since chemical treatment is expensive and uncertain, most individuals simply do not report the possible presence of the bug. The result is that the Red Weevil is infecting trees throughout Alicante (Hernández Bravo, 2013). Suburban landscapes in Alicante already bear the imprint of the pest in the brownish and decaying palm trees of many new roads and roundabouts.

\section{Discussion and conclusion: the emergence of new natures in the wake of socioecological crisis}

In political ecological terms, the ascent, changes, and subsequent decline of Alicante's ornamental trees - in terms of both market share and plant health-connect different scales, different agents (human and nonhuman), and different demographic, economic, and social factors. In scalar terms, the expansion of ornamentals is directly related to the speculative real estate boom in Spain and several other Anglo-European countries during the first years of the twentieth century. Agents intervening in the expansion and decline of ornamentals are both socioeconomic (the ascent and collapse of real estate speculation) and ecological (the proliferation of palm and olive trees and the devastating effects of the Red Weevil). The geography of the ornamentals in Alicante also reflects the historical rhythms of urbanization in the province, and particularly the pre-crisis influx of large numbers of European retirees who were eager to buy property in the less developed and less affluent southern region of the province.

In sum, the new social and ecological relationships emerging in Alicante constitute an expression of new natures associated with the boom and bust of urbanization via massive investment in residential construction from the 1990s until 2008. Our main argument is that urbanization does not erase nature, but rather produces new natural forms and relations that shift with the rhythms of different phases of urban development and capital (dis)investment. In Alicante and coastal Mediterranean Spain, a major expansion of low density urbanism has led to an expansion of surface areas used for gardening and landscaping, in both the public and private arenas. These new natures are also shaped by the history of the urbanization process and local environmental conditions. Due to a combination of cultural-aesthetic, ecological, and economic characteristics, palm trees and olive trees have come to occupy many of the new urbanizing spaces. This occurs on formerly agricultural land, changing therefore a predominantly agrarian landscape into one modeled after the aesthetics of suburban arid North America with the iconic image of the palm trees portraying sensations of relaxation and the "good life." Along with smaller shrubs and plants, these species adapt quite well to the local semiarid climate, especially in the south of the province, where water is expensive and most homeowners (many of them European retirees) do not have excess income to devote to plant irrigation. In these areas, it is relatively rare to find lawns or gardens with highly water-demanding species. This contrasts with suburban developments in arid or semiarid environments in parts of the Western United States or Australia, where newcomers tend to reproduce the gardens and the garden species of their more humid areas of origin. We suggest here that moderateincome European retirees buying housing in Alicante are motivated to keep water costs down; one way of doing so is to choose ornamental vegetation that needs relatively little water.

The collapse of real estate in Alicante since 2008 has slowed urbanization, devastated household and municipal budgets, and seriously affected ornamental plant farms. The damage caused by the Red Weevil beetle has contributed to the development of a 
socioecological crisis - the beetle is biologically devastating and socioeconomic conditions limit the ability of producers and municipalities to pay for treatment. The response to the beetle which is often the most efficient and budget-friendly is destruction of palm trees that are infected or suspected to be so. Farms are responding by cutting their stocks of palm trees and reorienting their production toward smaller plants and flowers. More than five years into this socioecological crisis, the imprint left by fast urbanization is taking a new physical form in the post-crisis landscape of Alicante. The new landscapes produced during the boom are both thriving and dying in a new, post-crisis geography of abandoned housing, abandoned residential construction, and infected trees abandoned to the ravages of the Red Weevil. However, the fragments of new natures begin to emerge: in the wake of abandonment, native plants spring up around abandoned housing and dead palms.

\section{Acknowledgments}

We thank the comments by the editor of the journal and by three referees, which have substantially improved the quality of the manuscript. All errors remain ours.

\section{Funding}

Financial support for this research was provided by the Spanish CICYT under grants [grant number CSO2009-12772-03-01], [grant number CSO2009-12772-03-03].

\section{Notes}

1. In other parts of Europe, particularly Italy, large contiguous swaths of land are used for the cultivation of ornamental plants.

2. Spanish statistical figures do not separate vegetable from ornamental species.

3. This is equal to approximately 458,000 new units every year, with a peak of 557,000 , on average, between 2001 and 2006.

4. In the south of the province, average income is approximately $€ 12,000$ per year (below the Valencia and Spanish averages), but in the North, it climbs to $€ 16,000$ per year (above the Valencian and Spanish averages) (Rovira, 2011). This may help to explain the important differences found in garden and garden species between these areas.

5. This decline is heavily related to the size of the municipality and the intensity of the previous urbanizing process.

6. However, the physical characteristics of palm trees and olive trees and their adaptation to the local climate meant that many trees survived, somewhat offsetting the new lack of public maintenance.

\section{References}

Askew, L. E., \& McGuirk, Pauline M. (2004). Watering the suburbs: Distinction, conformity and the suburban garden. Australian Geographer, 35(1), 17-37.

Banco de España. (2013). Deuda Pública Según el Protocolo de Déficit Excesivo (PDE) [Public debt according to the excessive deficit protocol]. Banco De España. Retrieved from http://www.bde. es/webbde/es/estadis/infoest/htmls/cdp.html

Bhatti, Mark \& Church, Andrew. (2004). Home, the culture of nature and meanings of gardens in late modernity. Housing Studies, 19(1), 37-51.

Blaine, Thomas W., Clayton, Susan, Robbins, Paul, \& Grewal, Parwinder S. (2012). Homeowner attitudes and practices towards residential landscape management in Ohio, USA. Environmental Management, 50(2), 257-271.

Burriel de Orueta, Eugenio. (2008). La "Década Prodigiosa" del Urbanismo Español (1997-2006) [The prodigious decade of Spanish urbanism (1997-2006)]. Scripta Nova: Revista Electrónica de Geografia y Ciencias Sociales, 12(270), 66. 
Confederación Española de Agricultores y Ganaderos (COAG). (2010). Anuario Agrario, 2009 [Agricultural yearbook 2009]. Madrid: COAG.

Conselleria de Agricultura. (2008). Plantas Ornamentales comercializadas en la Comunidad Valenciana: Campaña 2007 [Ornamental plants marketed in Valencia: 2007 campaign]. Valencia: Generalitat Valenciana.

de Agricultura, Ministerio, \& Ambiente, Alimentación y Medio. (2012). Anuario de Estadística Agraria [Yearbook of agricultural statistics]. Retrieved from http://www.magrama.gob.es/es/ estadistica/temas/estad-publicaciones/anuario-de-estadistica/default.aspx\#para2

Domene, Elena, \& Saurí, David. (2007). Urbanization and class-produced natures: Vegetable gardens in the Barcelona metropolitan region. Geoforum, 38(2), 287-298.

Domene, Elena, Saurí, David, \& Parés, Marc. (2005). Urbanization and sustainable resource use: The case of garden watering in the metropolitan region of Barcelona. Urban Geography, 26(6), 520-535.

Europa Press. (2013, September 1). Una Empresa Valenciana Destruye este Miércoles 3,000 Palmeras al no Poder Afrontar las Exigencias Sobre el Picudo. 20 Minutos.

European Environmental Agency. (2006). Urban sprawl in Europe: The ignored challenge, Report Number 10. Retrieved from http://www.eea.europa.eu/publications/eea_report./eea_report 10_2006.pdf

Federación de Cooperativas Agrarias de Murcia (FEOCAM). (2013). Informe de Valoración de la Campaña Agrícola 2012 [Report on the 2012 agricultural campaign]. Murcia: FEOCAM.

Gaja, Fernando. (2008). El Tsunami Urbanizador de la Costa Mediterránea [The urbanization Tsunami of the Mediterranean coast]. Scripta Nova: Revista Electrónica de Geografia y Ciencias Sociales, 12(270), 66.

Moales Gil, Alfredo. (1997). Aspectos Geográficos de la Horticultura de Ciclo Manipulado en España [Geographical aspects of manipulated cycle horticulture in Spain]. Alicante: Universidad de Alicante.

Gober, Patricia, Middel, Ariane, Brazel, Anthony, Myint, Soe, Chang, Heejung, Duh, Jiunn-Der, \& House-Peters, Lily. (2012). Tradeoffs between water conservation and temperature amelioration in Phoenix and Portland: Implications for urban sustainability. Urban Geography, 33(7), $1030-1054$.

González, Jesús M. (2010). The real estate and economic crisis: An opportunity for urban return and rehabilitation policies in Spain. Sustainability, 6(2), 1571-1601.

Harvey, David. (1996). Justice, nature and the geography of difference. Oxford: Blackwell.

Hernández Bravo, José Carlos. (2013, July 19). Localizado un Ejemplar de Picudo Rojo en Peña Rubia [A red weevil individual identified in Peña Rubia]. El Períodico de Villena.

Hernández Hernández, Maria, Moltó Mantero, Enrique, \& Rico Amorós, Antonio Manuel. (2008). Las Actividades Turístico-Residenciales en las Montañas Valencianas [Tourist and residential activities in the Valencian mountains]. Eria, 75, 77-97.

Heynen, Nick, Kaika, Maria, \& Swyngedouw, Erik. (Eds.). (2006). In the nature of cities: Urban political ecology and the politics of urban metabolism. London: Routledge.

Huete Nieves, Raquel \& Mantecón Terán, Alejandro. (2011). Más Allá del Turismo: Movilidad Residencial Europea y Nuevos Núcleos Urbanos [Beyond tourism: European residential mobility and new urban centers]. Boletín de la Asociación de Geógrafos Españoles, 56, 111-128.

Instituto Español de Comercio Exterior. (2011). Estadísticas Españolas de Comercio Exterior, varios años [Unpublished Spanish statistics on foreign trade, several years].

Leichenko, Robin M., \& Solecki, William D. (2005). Exporting the American dream: The Globalization of Suburban Consumption Landscapes. Regional Studies, 39(2), 241-253.

Hernandez Hernandez, Maria. (2013). Análisis de los Procesos de Transformación Territorial en la Provincia de Alicante (1985-2011) y su Incidencia en el Recurso Hídrico a Través del Estudio Bibliográfico [Analysis of the processes of land use change in the province of Alicante (1985-2011) and their repercussions on water: A bibliographical guide). Documents d'Anàlisi Geográfica, 59(1), 105-136.

Hernandez Hernandez, Maria, \& Morales Gil, Alfredo. (2009). La Hortofruticultura y las Aguas del Trasvase Tajo-Segura: Repercusiones Socioeconómicas [The fruit and vegetable sector and the Tajo-Segura water transfer: Socioeconomic impacts). In J. Melgarejo Moreno (Ed.), El Trasvase Tajo-Segura: Repercusiones Económicas, Sociales y Ambientales en la Cuenca del Segura [The Tajo-Segura water transfer: Economic, social and environmental impacts in the Segura river basin] (pp. 413-464). Alicante: CAM Cultural. 
Melgarejo, J., Martínez, J. J., \& Martínez, J. (2004). Productividad y Rentabilidad del Agua de Riego en la Provincia de Alicante [Productivity and profitability of irrigation water in the province of Alicante]. Alicante: Universidad de Alicante, Instituto del Agua y de las Ciencias Ambientales.

Ministerio de Hacienda y Administraciones Públicas. (2012). Datos Presupuestarios de las Entidades Locales (2003-2012) [Budget data of local entities (2003-2012)]. Retrieved from $\mathrm{http} / /$ serviciosweb.meh.es/apps/EntidadesLocales/

Munoz, Francesc. (2003). Lock-living: Urban sprawl in Mediterranean cities. Cities, 20(6), 381-385.

Naredo Antrazyt, José Manuel \& Montiel Márquez, Antonio. (2011). El Modelo Inmobiliario Español y su Culminación en el Caso Valenciano [The Spanish real estate model and its culmination in Valencia]. Barcelona: Icaria.

Observatorio de la Sostenibilidad en España. (2011). Sostenibilidad en España 2010 [Sustainability in Spain 2010]. Madrid: Ministerio de Medio Ambiente, Fundación Biodiversidad and Fundación Universidad de Alcalá.

Parés, Marc, March, Hug, \& Saurí, David. (2013). Atlantic gardens in Mediterranean climates: Understanding the production of suburban natures in Barcelona. International Journal of Urban and Regional Research, 37(1), 328-347.

Peet, Richard, Robbins, Paul, \& Watts, Michael. (Eds.). (2010). Global political ecology. London: Routledge.

Robbins, Paul. (2004). Political ecology. Oxford: Blackwell.

Robbins, Paul. (2007). Lawn people. How grasses, weeds and chemicals make us who we are. Philadelphia, PA: Temple University Press.

Romero, Juan, Jimenez, Fernando, \& Villoria, Manuel. (2012). (Un)sustainable territories: Causes of the speculative bubble in Spain (1996-2010) and its territorial, environmental, and sociopolitical consequences. Environment and Planning C, 30(3), 467-486.

Rovira, A. (Ed.). (2011). Atlas Socio-Comercial de la Comunitat Valenciana 2009 [Social and economic Atlas of Valencia 2009]. Valencia: Generalitat Valenciana and Consejo de Cámaras Oficiales de Comercio, Industria y Navegación de la Comunidad Valenciana.

Rullan, Onofre. (2012). Urbanismo Expansivo en el Estado Español: De la Utopía a la Realidad [Expansive urbanism in Spain: From utopia to reality]. In V. Gozálvez Pérez \& J. A. Marco Molina (Eds.), Geografia. Retos Ambientales y Territoriales [Geography and environmental and territorial challenges] (pp. 165-209). Alicante: XXII Congreso de la Asociación de Geógrafos Españoles Alicante, Universidad de Alicante.

Smith, Neil. (1984). Uneven development. Oxford: Blackwell.

Swyngedouw, Erik. (2004). Social power and the urbanization of water. Oxford: Oxford University Press.

Turner, Tom. (2010). European gardens: History, philosophy and design. London: Routledge. 